\title{
Stock Market Volatility, Speculative Short Sellers and Weekend Effect: International Evidence
}

\author{
Weili Zhai ${ }^{1}$, Hossein S. Kazemi ${ }^{2 *}$, Jibao $\mathrm{He}^{3 \#}$, Jinghan Cai ${ }^{4}$ \\ ${ }^{1}$ Department of Finance, Shenzhen University, Shenzhen, China \\ ${ }^{2}$ Department of Economics, Stonehill College, Easton, USA \\ ${ }^{3}$ Shenzhen Stock Exchange, Shenzhen, China \\ ${ }^{4}$ Department of Economics, Boston College, Boston, USA \\ Email: zhaiweili2006@126.com, "kazemi@stonehill.edu, jbhe@szse.cn,jinghan.cai@bc.edu
}

Received June $15^{\text {th }}, 2013$; revised July $15^{\text {th }}, 2013$; accepted July $22^{\text {nd }}, 2013$

Copyright (C) 2013 Weili Zhai et al. This is an open access article distributed under the Creative Commons Attribution License, which permits unrestricted use, distribution, and reproduction in any medium, provided the original work is properly cited.

\begin{abstract}
We test the Chen and Singal (2003) hypothesis that speculative short sellers add to the selling pressure on Mondays, and hence add to the weekend effect, by examining evidence from 60 market indices. We find strong evidence that, until about a decade ago, the actions of short sellers could explain the weekend effect. Recently, however, the relationship between short sales and the weekend effect is gradually dissipating in developed markets, probably due to the cross-market hedges of short sellers. These findings strongly support, rather than weaken, the Chen and Singal hypothesis.
\end{abstract}

Keywords: Weekend Effect; Short Sales; Market Anomaly; Stock Market Volatility

\section{Introduction}

We provide empirical evidence, from an international perspective, to document the long standing weekend effect and its relation with short sales. This paper is an expanded and enhanced version of the authors' previous paper $^{1}$ on this topic. The research on the weekend anomaly begins with French (1980), who studies the S\&P 500 Index over the period 1953 through 1977, and with Gibbons and Hess (1981) who study the S\&P 500 Index and the CRSP value-and-equal-weighted indexes for NYSE and AMEX securities over the period 1962 through 1978. After that, there is much evidence in support of systematically lower returns on Mondays. Keim and Stambaugh (1984) find that Friday returns are lower when there is Saturday trading. Ariel (1990) finds that the value of a significantly larger number of stocks increases pre-holiday rather than post-holiday. Wang et al. (1997) find that lower returns systematically occur on Mondays in the second half of a month.

In addition to the US stock market, researchers have also documented weekend effects in other equity markets. Hindmarch et al. (1984) find a weekend effect in the Canadian market. Jaffe and Westerfield (1985) find weekday effects similar to those in the US market for the Canadian, British, Japanese, and Australian equity markets. Condoyanni et al. (1989)find significantly negative Monday or Tuesday returns in a study including seven developed markets. Chang et al. (1993) find significantly negative Monday returns in 13 of 23 international markets. Dubois and Louvet (1996) provide further evidence of the existence of low Monday returns for developed markets in an examination

\footnotetext{
"Corresponding author.

\#Jibao He acknowledges supports from NSFC project 71172226/G0206.

${ }^{1}$ Jinghan Cai, Hossein S. Kazemi, Jibao He and Weili Zhai "Weekend Effect and Short Sales: International Evidence". International Advances in Economic Research. May 2013, Volume 19, Issue 2, 209-211.
}

of eleven indices from nine countries during the period 1969 through 1992. Cai et al. (2006) document a pattern similar to that found by Wang et al. (1997), i.e., they find that, in the Chinese stock market also, weekend effects mainly occur in the second half of a month.

Many researchers propose potential explanations for the weekend effect. Keim and Stambaugh (1984) establish that the phenomenon has been a regular feature of the financial landscape for many years, and they reject the possibility that it arises from measurement error. Keim (1989) finds that the bid ask bounce can explain about 17 percent of the weekend effect. Lakonishok and Maberly (1990), Abraham and Ikenberry (1994) and Chan et al. (2004) attribute part of the weekend effect to the differential trading patterns or holding preferences of institutions and individuals. Sias and Starks (1995) also document an association between the weekend effect and institutional ownership.

More recently, Chen and Singal (2003) propose a new explanation, i.e., that the weekend effect might be linked to short sales. They argue that, unlike a long position whose potential loss is limited, a short position faces theoretically unlimited downside risks. Thus short positions require closer monitoring. Since short sellers cannot close their positions during non-trading hours, they tend to close their positions by the weekend to avoid the potential losses which might occur during the long period of non-trading. Empirically, Chen and Singal (2003) find that stocks with high short interest experience a relatively greater weekend effect than stocks with low short interest, which directly supports their hypothesis.

However, recently some researchers have issued evidence that is contrary to Chen and Singal's (2003) findings. For example, Blau et al. (2007) do not find that short selling is more abundant on Mondays. Christophe et al. (2006) distinguish short sales by dealers from those by customers, but they find no evi- 
dence that the Monday-Friday return differences are closely linked to the Monday-Friday differences in either type of short sales.

To clarify whether short sales play a significant role in explaining the weekend effect, we extend the empirical tests. Using the daily stock index returns from 60 markets, we find that, during the period from 1980 to 1994 , the practice of short sales can in fact explain the weekend effect; however, during the period from 1995 to 2007, the cross-sectional weekend effect cannot be explained by the practice of short sales. Our findings imply that the hypothesis proposed by Chen and Singal (2003) used to work well, but that it has actually been losing its effectiveness during the last decade, especially in developed markets. One potential explanation is that short sellers in developed markets can now hedge worldwide, and they do not need to be limited to a single market, while short sellers in developing markets, in contrast, have to balance their short positions within the local markets due to strict capital account controls. In order to test this explanation, we separate the developed markets from the developing markets, and test the relationship between short sales and the weekend effect in each case. Our findings are highly consistent with the explanation that the weakened impact of short sales on the weekend effect is due to cross-market hedges. Our findings provide sound evidence to support Chen and Singal's (2003) hypothesis and help explain why others such as Christophe et al. (2006) and Blau et al. (2007) cannot find results consistent with findings of (2003).

The rest of the paper is arranged as follows: Section 2 explains the data source and sample characteristics, Section 3 shows the empirical results, Section 4 is the robust check, and Section 5 concludes.

\section{The Data}

We obtained daily index data from the CEIC Daily Database. Our dataset contains 60 market indices from 59 countries $^{2}$. For each country, we begin our analysis on January $1^{\text {st }}, 1980$, or on the first date for which CEIC data is available, whichever comes later. The appendix lists a detailed list of markets and the beginning date used in our paper. We define the daily return of index $i$ on day $t$ as

$$
r_{i, t}=\log \left(I_{i, t}\right)-\log \left(I_{i, t-1}\right)^{3} .
$$

where $I_{i, t}$ refers to the price index $i$ on day $t$.

The information about the availability of short sales in each market is from Charoenrook and Daouk (2005). The details can also be in the Appendix. We can see that of the 60 indices (60 markets from 59 countries), 27 are from markets where short sales are allowed and practically feasible, while the other 33 are from markets where short sales are either legally prohibited or practically not feasible. We further divide the 60 sample indices into two subsamples: the developed markets and the developing markets. 27 indices are identified as coming from developed economies, while the other 33 are from developing economies ${ }^{4}$.

Table 1 shows the basic information about the weekend effect in the 60 markets. For each market, we first run the fol-

${ }^{2}$ For the US, we use both the Dow Jones Index and the S\&P 500. For other countries, only one major stock index is used.

${ }^{3}$ We drop any observations with the daily return higher than $20 \%$ or lower than $-20 \%$. 48 observations are therefore deleted, comprising less than $0.1 \%$ of the total number of observations.

${ }^{4}$ We adopt the standards from the IMF 1997 World Economic Outlook.
Table 1.

Descriptive statistics.

\begin{tabular}{cccc}
\hline Panel A: $\beta_{i}$ & Full sample & $\begin{array}{c}\text { Before } \\
\mathbf{1 9 9 5}\end{array}$ & After 1995 \\
\hline Total market number & 60 & 37 & 60 \\
\# of negative $\beta_{i}(\%)$ & $45(75.00)$ & $28(75.68)$ & $38(63.33)$ \\
\# of $-\&$ sig. $\quad \beta_{i}(\%)$ & $23(38.33)$ & $19(51.35)$ & $15(25.00)$ \\
\# of + \& sig. $\quad \beta_{i}(\%)$ & $2(3.33)$ & $1(2.70)$ & $2(3.33)$ \\
\hline Note: Panel A is based on the coefficient of model (1). & Before 1995 & After 1995 \\
\hline Panel B: return & Full sample & -0.064 & 0.025 \\
\hline Mondays (\%) & 0.019 & 0.098 & 0.065 \\
Other days $(\%)$ & 0.073 & -3.51 & -2.60 \\
t-value & -3.62 & 0.001 & 0.012 \\
\hline p-value & 0.001 & &
\end{tabular}

lowing model (1):

$$
r_{i t}=\alpha_{i}+\beta_{i} M_{O N D U M}+\varepsilon_{i t}
$$

Where $r_{i t}$ is the daily return of market $i$ on date $t$. MONDUM $M_{i t}$ is a dummy variable which takes the value of 1 if date $t$ is a Monday and 0 otherwise ${ }^{5}$. We can see from the table that of the 60 markets, 45 have negative coefficients for the variable $M O N$ $D U M_{i t}$, making up $75 \%$ of the total number of markets. Among these 45 markets, 23 have coefficients that are significantly negative. Comparatively, only 2 out of the 60 indices carry positive and significant coefficients for MONDUM $M_{i t}$.

We further divide our total sample period into two sub-periods-before Jan 1, 1995 and after Jan 1, 1995-to see whether the negative coefficients happen in some specific sub-period. The sub-period results show a change from sub-period 1 to sub-period 2. In sub-sample 1, 28 out of $37(75.68 \%)$ indices show negative coefficients for the variable $M O N D U M_{i t}{ }^{6}$, and $19(51.35 \%)$ are significant. However, in sub-sample 2, only 38 out of 60 coefficients $(63.33 \%)$ are negative, and only $15(25 \%)$ are significant. These results are consistent with the existing literature, which has found that the weekend effect has been getting weaker recently.

In Panel B, we show the cross sectional means and medians of average Monday returns and of other weekday returns for each index. We can see that for the full sample, the mean of average Monday returns for the 60 indices is $0.019 \%$, significantly ( $1 \%$ level, with $t$-value of -3.62$)$ lower than that of the other weekday returns $(0.073 \%)$. The median of average Monday returns is $0.018 \%$, also significantly ( $1 \%$ level, with z-value of $-3.27)$ lower than that of the other weekday returns $(0.058 \%)$. We also test this difference in the two sub-samples, and the same pattern appears in both.

In summary, the results obtained in this section confirm the existing literature in the following two aspects: First, the

${ }^{5}$ Note that for markets (Bangladesh, Jordan, Egypt, Saudi Arabia and Israel) where the first day after the weekend is not Monday, MON$D U M_{i t}$ takes the value of 1 for the first trading day after the weekend. This applies to all the MONDUM $M_{i t}$ variables in this paper.

${ }^{6} 23$ indices do not have data before Jan. 1, 1995. 
weekend effect is a world-wide phenomenon; Secondly, the degree of the weekend effect has been getting weaker in the recent decade, compared with one decade ago.

\section{Short Sales and the Weekend Effect}

Chen and Singal (2003) explain the weekend effect by introducing the potential impacts of short sellers. It is well known that stock returns for unhedged short positions are theoretically unbounded. Also, researches such as Asquith and Muelbroek (1996) and DeChow et al. (2001) have noted that unhedged short positions face higher risks. All these facts indicate that an uncovered short exposure needs close watching to minimize the chance of large losses due to a price increase. Non-trading hours will therefore incur more risks than usual because short sellers are unable to adjust their positions. Based on these arguments, Chen and Singal (2003) believe that short sellers tend to close their positions before the weekend, and to reopen them on Mondays. This leads to lower average Monday returns.

In this section we test whether short sales explain the weekend effect worldwide. If Chen and Singal's (2003) story is true, in the markets allowing short sales, the weekend effect will be stronger than where short sales are prohibited. Therefore, we introduce the following regression models:

$$
\begin{gathered}
r_{i t}=\alpha_{i}+\beta_{i} \text { MONDUM }_{i t}+\varepsilon_{i t} \\
r_{i t}=\alpha_{i}+\beta_{i} \text { MONDUM }_{i t}+\gamma_{i} \text { CMON }_{i t}+\varepsilon_{i t} \\
r_{i t}=\alpha_{i}+\beta_{i} \text { MONDUM }_{i t}+\gamma_{i} \text { CMON }_{i t}+\varepsilon_{i t}
\end{gathered}
$$

where $r_{i t}$ is the daily return of market $i$ on date $t$. MONDUMit is a dummy variable which takes the value of 1 if date $t$ is a Monday and 0 otherwise. $C M O N_{i t}$ is the interaction term of a short sale dummy ( 1 if the market allows short sales and 0 otherwise) and the MONDUM . $_{\text {. }}$

Table 2 shows the results of a pooled regression of models (1) and (2). For the full sample, the coefficient of MONDUM $M_{i t}$ in model (1) is $-0.066 \%$, significant at $1 \%$ level, meaning that the weekend effect does exist around the world. After entering the interaction term, the coefficient of $M O N D U M_{i t}$ in model (2) changes to $-0.039 \%$, less negative than in regression (1), meaning that short sales do explain a large part of the weekend effect. On average, the Monday return of a firm in a market allowing

Table 2.

Pooled regression results.

\begin{tabular}{ccccccc}
\hline \multicolumn{3}{c}{ Full sample } & \multicolumn{2}{c}{ Before 1995 } & \multicolumn{2}{c}{ After 1995 } \\
\hline Unit: $10^{-3}$ & $(1)$ & $(2)$ & $(1)$ & $(2)$ & $(1)$ & $(2)$ \\
& $-0.66^{* *}$ & $-0.39^{* *}$ & $-1.26^{* *}$ & -0.24 & $-0.45^{* *}$ & $-0.39^{* *}$ \\
MONDUM & $(-8.57)$ & $(-3.73)$ & $(-9.37)$ & $(-1.03)$ & $(-4.87)$ & $(-3.30)$ \\
& & $-0.50^{* *}$ & & $-1.46^{* *}$ & & -0.12 \\
CMON & & $(-3.68)$ & & $(-5.54)$ & & $(-0.71)$ \\
& & & & & \\
Cons & $0.67^{* *}$ & $0.67^{* *}$ & $0.83^{* *}$ & $0.83^{* *}$ & $0.61^{* *}$ & $0.61^{* *}$ \\
& $(19.73)$ & $(0.00)$ & $(14.22)$ & $(14.24)$ & $(14.90)$ & $(14.90)$ \\
F-value & 73.47 & 43.50 & 87.87 & 59.30 & 23.74 & 12.12 \\
Prob > F & 0.000 & 0.000 & 0.000 & 0.000 & 0.000 & 0.000 \\
$\mathrm{R}^{\wedge} 2(\%)$ & 0.03 & 0.04 & 0.15 & 0.20 & 0.01 & 0.01 \\
\hline
\end{tabular}

Note: This table is based on models (1) and (2). t-values are in parentheses; " and ${ }^{* *}$ represent significance level at $5 \%$ and $1 \%$ respectively. t-values are in parentheses. short sales is $0.050 \%$ lower than the Monday return from a marketnot allowing short sales. And the Monday return of a firm in a short-sale allowing market is $-0.089 \%(-0.039+$ $(-0.050))$ lower than the non-Monday return of a firm in a market where short sales are not allowed.

The sub-sample results show a pattern different from the full sample. In the first sub-sample, the coefficient of MONDUM $M_{i t}$ in model (1) is $-0.126 \%$, meaning that the weekend effect exists around the world before 1995. After entering $C M O N_{i t}$, the coefficient of MONDUM $M_{i t}$ gets insignificant, and the coefficient of $C M O N_{i t}$ is significantly negative, implying that short sales can explain most of the weekend effect before 1995 .

However, in the second sub-sample, the coefficient of $C M O N_{i t}$ is now $-0.012 \%$ (not significant), and $M O N D U M_{i t}$ is still negatively significant. This pattern indicates that, after 1995 , the actions of short sellers cannot explain the weekend effect.

We argue that the difference in the two sub-samples actually supports Chen and Singal's (2003) story, rather than weakens it: until about a decade ago, the world's stock markets were more isolated, and capital flows were not as convenient as they are today. Hence, cross-market hedges were not often employed, and short sellers had to adjust their positions mainly within the local market. Thus the practice of closing and re-opening short positions around the weekend was necessary and frequent, leading to the prominent weekend effect. However, with the converging trend of the world's stock markets, capital flows between markets became easier and encountered fewer obstacles. Short sellers are now getting more comfortable at managing their positions worldwide, rather than staying within one single market. Also, investors have incentives to hedge their short positions across markets because by doing so they can reduce the transaction costs incurred by closing and rebuilding short positions within a single market. This explains why the weekend effect was more prominent a decade ago, but less prominent in the recent decade.

Moreover, we want to separate developed from developing markets, which is important because capital flows and crossmarket hedges will happen more in developed markets since in most developing markets capital accounts are still under strict control. This means that, if our explanation above is correct, the impact of short sellers' actions should decrease by more in developed markets than in developing ones. When it comes to developed markets, capital flows and cross-market hedges become more available throughout this time period, and so short sellers' actions should have a decreased impact in the latter subsample. We spell all this out in the predictions in Table 3.

Pattern 1: In the full sample, short sellers' actions can explain the weekend effect in developing markets, since even at the present time, capital accounts in developing economies are still strictly controlled, and capital free flow is not expected. However, in the developed markets, the impact of short sales on the weekend effect is more ambiguous.

Table 3.

Comparison between developed and developing markets - predictions.

\begin{tabular}{ccc}
\hline $\begin{array}{c}\text { The impacts of short sales on } \\
\text { weekend effects }\end{array}$ & $\begin{array}{c}\text { Developed } \\
\text { markets }\end{array}$ & $\begin{array}{c}\text { Developing } \\
\text { markets }\end{array}$ \\
\hline Full sample & Ambiguous & Strong \\
Before $\mathbf{1 9 9 5}$ & Strong & Strong \\
After $\mathbf{1 9 9 5}$ & Weak & Strong \\
\hline
\end{tabular}


Pattern 2: In sub-sample 1, (before 1995) short sellers' actions can explain the weekend effect in developed and developing markets, since capital market conglomerations were not prevailing even in developed markets, and so short sellers everywhere had to adjust their short positions mainly within a single market only.

Pattern 3: In sub-sample 2, (after 1995) short sellers' actions can explain the weekend effect in developing markets. For developed markets, we do not expect to observe negative and significant coefficients of $C M O N_{i t}$ because, after 1995, the impact of short sales on the weekend effect in developed markets is weakened due to capital market conglomerations.

In order to empirically test the patterns from Table 3, we introduce Table 4 for the pooled regressions based on equations (1) and (2) as shown earlier and all variables are defined the same. The empirical results in Table 4 are highly consistent with the predictions in Table 3 . In the full sample, the coefficients of $C M O N_{i t}$ are not significant for the developed markets, while the coefficients of $C M O N_{i t}$ for the developing markets are significantly negative, confirming the predictions in Pattern 1. In the subsample before 1995, the coefficients of $C M O N_{i t}$ for both the developing and the developed markets are negative and significant, confirming the predictions in Pattern 2. Moreover, after controlling for the impact of short sales, the coefficients of MONDUM $M_{i t}$ become less negative, especially for the developed markets, indicating that the impact of short sellers' actions can explain the weekend effect to a large extent. In the subsample after 1995, the coefficients of $C M O N_{i t}$ for developed markets are now positive, indicating that, in the recent decade or so, short sellers' actions cannot explain the weekend effect. This is because short sellers in developed markets may now hedge in other markets, rather than adjust their positions within one market. However, in developing markets the coefficients of $C M O N_{i t}$ are still negative and significant, implying that in developing markets investors cannot easily hedge across markets; short sellers still have to adjust their positions around the weekends, leading to a strong impact on the weekend effect. Our empirical results strongly support Chen and Singal's (2003) findings that the weekend effects are partly caused by the actions of short sellers' position adjustments.

\section{Robust Check}

\section{Different Sub Periods}

Up until now we set the early sub-sample as the period before Jan $1^{\text {st }}, 1995$, and the recent sub-sample as the period on or after Jan $1^{\text {st }}, 1995$. The selection of this breaking date is somewhat arbitrary. In order to reduce potential bias, we also selected different dates as breaking points, and re-examined the abovementioned tests. We tried Jan $1^{\text {st }}, 1996$, Jan $1^{\text {st }}$, 1997, Jan $1^{\text {st }}$, 1998, Jan $1^{\text {st }}, 1999$ and Jan $1^{\text {st }}, 2000$. The results for all these dates are highly consistent with what we found when we used Jan $1^{\text {st }} 1995$.

\section{Consistent Sub-samples before and after 1995}

From Table 1 we can see that in the after 1995 sub-sample, there are 60 indices, but that in the before 1995 sub-sample, there are only 37 indices. The problem is that either the indices do not date back to before 1995, or that the CEIC database does not contain data for before 1995. This leads to the question of whether this sample difference leads to any bias. To answer this question, we kept only the 37 indices that have data before 1995, and re-performed all the above regressions on them alone.
The results are highly consistent with those in Table 5, indicating that the different number of indices before and after 1995 does not lead to severe bias.

\section{Short Sales and Put Options}

Chen and Singal (2003) also provide a substitute explanation besides short selling: the put option. They empirically document that traders use options when available in preference to short selling, possibly causing the weekend effect to dissipate. Following this line, we also consider the substitution effect of put options for short sales. The following model (3) is thus introduced:

$$
\begin{gathered}
r_{i t}=\alpha_{i}+\beta_{i} \text { MONDUM }_{i t}+\gamma_{i} \text { CMON }_{i t}+\varepsilon_{i t} \\
r_{i t}=\alpha_{i}+\beta_{i} \text { MONDUM }_{i t}+\gamma_{i} \text { CMON }_{i t}+\delta_{i} \text { PMON }_{i t}+\varepsilon_{i t}
\end{gathered}
$$

where $_{i t}$ is the daily return of market $i$ on date $t$. MONDUM $M_{i t}$ is a dummy variable which takes the value of 1 if date $t$ is a Monday and 0 otherwise. $C M O N_{i t}$ is an interaction term of a short sale dummy ( 1 if the market allows the practice of short sales and 0 otherwise) and the MONDUM $M_{i t} . P M O N_{i t}$ is an interaction term of a put option dummy ( 1 if the market allows the practice of put options and 0 otherwise) and the MONDUM ${ }_{i t}{ }^{7}$.

Table 5 shows empirical results different from Chen and Singal's (2003). The entering of $P M O N_{i t}$ does not affect the relationship between short sales and the weekend effect. The patterns documented in Table 5 do not change at all, and the impact of the put options on the weekend effect is trivial.

\section{Discussion and Conclusions}

The weekend effect is a research field full of discussions and controversies. Ever since French (1980), many researchers document the existence of it and provide numerous potential explanations. Recently, Chen and Singal (2003) propose an explanation that the weekend effect might be linked to short sales. They argue that since short sellers cannot close positions during the weekend, they tend to close their positions before the weekend and to re-open them on Mondays in order to avoid potential losses. However, other papers-such as Christophe et al. (2006), and Blau et al. (2007) — declare that there is no empirical evidence to support Chen and Singal's (2003) explanations.

In this paper, we examine the relationship between short sales and the weekend effect from an international perspective. Using 60 indices from around the world, we document the following patterns: In the full sample (both before and after 1995) short sellers' actions can explain the weekend effect in developing markets but not in developed ones. In sub-sample 1 (before 1995) the short sellers' actions can explain the weekend effect both in developed and developing markets. In sub-sample 2, (after 1995) short sellers' actions can explain the weekend effect in developing markets but not in developed ones. These results are independent of various potential biases.

We propose a new potential explanation: the position adjustments of short sellers cause the weekend effect if the investors have to balance their positions in the local markets. This phenomenon was prevalent everywhere until about a decade ago, and is still prevalent even today in developing markets where capital accounts are strictly controlled and cross-market hedges are

\footnotetext{
${ }^{7}$ The data about the availability of put options in each market are also from Charoenrook and Daouk (2004).
} 
Table 4.

Comparison between developed and developing economies - empirical evidence.

\begin{tabular}{ccccccccccccc}
\hline & \multicolumn{3}{c}{ Full sample (60 indices) } & \multicolumn{2}{c}{ Sub-sample1: Before 1995 (37 indices) } & \multicolumn{3}{c}{ Sub-sample 2: After 1995 (60 indices) } \\
\hline \multirow{2}{*}{ Unit: $10^{-3}$} & $\begin{array}{c}\text { Developed } \\
\text { markets }\end{array}$ & \multicolumn{2}{c}{$\begin{array}{c}\text { Developing } \\
\text { markets }\end{array}$} & \multicolumn{2}{c}{$\begin{array}{c}\text { Developed } \\
\text { markets }\end{array}$} & $\begin{array}{c}\text { Developing } \\
\text { markets }\end{array}$ & \multicolumn{2}{c}{$\begin{array}{c}\text { Developed } \\
\text { markets }\end{array}$} & $\begin{array}{c}\text { Developing } \\
\text { markets }\end{array}$ \\
\hline & $(1)$ & $(2)$ & $(1)$ & $(2)$ & $(1)$ & $(2)$ & $(1)$ & $(2)$ & $(1)$ & $(2)$ & $(1)$ & $(2)$ \\
MONDUM & -0.531 & -0.397 & -0.822 & -0.572 & 1.145 & -0.115 & -1.653 & -0.834 & -0.208 & -0.514 & -0.683 & -0.515 \\
& $(-6.23)$ & $(-2.29)$ & $(-6.06)$ & $(-3.88)$ & $(-8.76)$ & $(-0.42)$ & $(-4.47)$ & $(-1.85)$ & $(-1.88)$ & $(-2.34)$ & $(-4.69)$ & $(-3.30)$ \\
CMON & & -0.170 & & -1.329 & & -1.207 & & -2.159 & & 0.394 & -1.081 \\
& & $(-0.89)$ & & $(-4.29)$ & & $(-4.22)$ & & $(-3.18)$ & & $(0.106)$ & $(-3.01)$ \\
Constant & 0.484 & 0.484 & 0.906 & 0.906 & 0.628 & 0.628 & 1.507 & 1.507 & 0.406 & 0.406 & 0.807 & 0.807 \\
F-value & $(13.00)$ & $(13.00)$ & $(14.90)$ & $(14.90)$ & $(11.73)$ & $(11.13)$ & $(8.97)$ & $(8.97)$ & $(8.34)$ & $(8.34)$ & $(12.38)$ & $(12.38)$ \\
Prob > F & 38.83 & 19.81 & 36.77 & 27.59 & 76.45 & 47.31 & 19.98 & 15.06 & 3.52 & 3.06 & 22.04 & 15.55 \\
R^2 (\%) & 0.000 & 0.000 & 0.000 & 0.000 & 0.000 & 0.000 & 0.000 & 0.000 & 0.061 & 0.047 & 0.000 & 0.000 \\
\hline
\end{tabular}

Note: This table is the pooled regression results based on models (1) and (2). t-values are in parentheses.

Table 5.

The impacts of put options.

\begin{tabular}{|c|c|c|c|c|c|c|}
\hline \multirow[b]{2}{*}{ Unit: $10^{-3}$} & \multicolumn{2}{|c|}{ Full sample (60 indices) } & \multicolumn{2}{|c|}{$\begin{array}{l}\text { Before } 1995 \\
\text { (37 indices) }\end{array}$} & \multicolumn{2}{|c|}{$\begin{array}{l}\text { After } 1995 \\
\text { (60 indices) }\end{array}$} \\
\hline & $\begin{array}{l}\text { Developed } \\
\text { markets }\end{array}$ & $\begin{array}{l}\text { Developing } \\
\text { markets }\end{array}$ & $\begin{array}{l}\text { Developed } \\
\text { markets }\end{array}$ & $\begin{array}{l}\text { Developing } \\
\text { markets }\end{array}$ & $\begin{array}{l}\text { Developed } \\
\text { markets }\end{array}$ & $\begin{array}{l}\text { Developing } \\
\text { markets }\end{array}$ \\
\hline Model: & (3) & (3) & (3) & (3) & (3) & (3) \\
\hline MONDUM & $\begin{array}{l}-0.628^{* *} \\
(-2.57)\end{array}$ & $\begin{array}{c}-0.623^{* *} \\
(-3.65)\end{array}$ & $\begin{array}{l}0.612 \\
(1.23)\end{array}$ & $\begin{array}{l}-1.420^{*} \\
(-2.31)\end{array}$ & $\begin{array}{c}-0.821^{* *} \\
(-2.86)\end{array}$ & $\begin{array}{c}-0.501^{* *} \\
(-2.82)\end{array}$ \\
\hline CMON & $\begin{array}{l}-0.258 \\
(-1.29)\end{array}$ & $\begin{array}{c}-1.350^{* *} \\
(-4.33)\end{array}$ & $\begin{array}{l}-1.295^{* *} \\
(-4.30)\end{array}$ & $\begin{array}{l}-2.025^{* *} \\
(-2.96)\end{array}$ & $\begin{array}{l}0.171 \\
(0.62)\end{array}$ & $\begin{array}{l}-1.072^{* *} \\
(-2.96)\end{array}$ \\
\hline PMON & $\begin{array}{l}0.341 \\
(1.34)\end{array}$ & $\begin{array}{l}0.150 \\
(0.59)\end{array}$ & $\begin{array}{l}-0.768 \\
(-1.77)\end{array}$ & $\begin{array}{l}0.939 \\
(1.40)\end{array}$ & $\begin{array}{l}0.553 \\
(1.66)\end{array}$ & $\begin{array}{l}-0.045 \\
(-0.16)\end{array}$ \\
\hline Constant & $\begin{array}{l}0.484^{* *} \\
(13.00)\end{array}$ & $\begin{array}{l}0.906^{* *} \\
(14.90)\end{array}$ & $\begin{array}{l}0.628^{* *} \\
(11.13)\end{array}$ & $\begin{array}{l}1.507^{* *} \\
(8.97)\end{array}$ & $\begin{array}{c}0.406^{* *} \\
(8.34)\end{array}$ & $\begin{array}{l}0.807^{* *} \\
(12.38)\end{array}$ \\
\hline F-value & 13.81 & 18.51 & 32.58 & 10.69 & 2.96 & 10.38 \\
\hline Prob $>$ F & 0.000 & 0.000 & 0.000 & 0.000 & 0.031 & 0.000 \\
\hline Adj R-square(\%) & 0.03 & 0.05 & 0.21 & 0.21 & 0.01 & 0.03 \\
\hline
\end{tabular}

Note: ${ }^{*}$ and ${ }^{* *}$ represent significance level at $5 \%$ and $1 \%$ respectively. $t$-values are in parentheses.

not as easy. However, the weekend effect dissipates in developed markets in the recent decade because short sellers can now hedge internationally rather than being limited to local markets. This is a strong support for Chen and Singal's (2003) story.

Recently more and more researchers tend to explain the weekend effect through the investigation of intraday patterns. They thus tend to use a relatively short sample period (one year, for example) due to the large volume of data. However, considering the empirical results of this paper, we have enough evidence to argue that too short a sample period may lead to the study of an already weakened weekend effect (especially fordeveloped markets). This explains why recent studies cannot find empirical evidence to support Chen and Singal (2003). For example, Blau, et al. (2007) use a one-year sample of the NYSE listed stocks, and declare that they do not find abundant short selling on Mondays. Christophe, et al. (2006) use NASDAQ stocks from September 2000 to July 2001 and find no test which supports the idea that the Monday-Friday return differences are closely linked to the Monday-Friday differences in short sales. But since both of these studies employ US data (a developed market) in the recent decade, the relationship be- tween short sales and the weekend effect has already largely dissipated because of the existence of cross-markets hedging. So their evidence cannot be considered to be weakening Chen and Singal's (2003) conclusion.

\section{REFERENCES}

Ariel, R. (1990). High stock returns before holidays: Existence and evidence on possible causes. Journal of Finance, 45, 1611-1626. doi:10.1111/j.1540-6261.1990.tb03731.x

Asquith, P., \& Muelbroek, L. (1996). An empirical investigation of short interest, working paper.

Abraham, A., \& Ikenberry, D. (1994). The individual investor and the weekend effect. Journal of Financial and Quantitative Analysis, 29, 263-277. doi: $10.2307 / 2331225$

Blau, B., Van Ness, B., \& Van Ness, R. (2007). Short selling and the weekend effect for NYSE securities, working paper.

Cai, J., Li, Y., \& Qi, Y. (2006). The day of the week effect: New evidence from Chinese stock market. The Chinese Economy, 39, 71-88. doi:10.2753/CES1097-1475390206

Cai, J., Kazemi, H. S., He, J., \& Zhai, W. (2013). Weekend effect and short sales: International evidence. International Advances in Eco- 
nomic Research, 19, 209-211. doi:10.1007/s11294-013-9398-Z

Chan, S. H., Leung, W. K., \& Wang, K. (2004). The impact of institutional investors on the Monday seasonal. Journal of Business, 77, 967-986. doi:10.1086/422630

Chang, E., Pinegar, J., \& Ravichandran, R. (1993). International evidence on the robustness of the day-of-the-week effect. Journal of Financial and Quantitative Analysis, 28, 497-513. doi: $10.2307 / 2331162$

Charoenrook, A., \& Daouk, H. (2005). The world pricing of short selling, working paper.

Chen, H., \& Singal, V. (2003). Role of speculative short sales in price formation: The case of the weekend effect. Journal of Finance, 58, 685-705. doi:10.1111/1540-6261.00541

Christophe, S., Ferri, M., \& Angel, J. (2006). Short selling and the weekend effect in stock returns, working paper.

Condoyanni, I., O'Hanlon, J., \& Ward, C. W. R. (1989). Day of the week effects on stock returns: International evidence. Journal of Business Finance and Accounting, 14, 159-174.

doi:10.1111/j.1468-5957.1987.tb00536.x

DeChow, P., Hutton, A. Meulbroek, L., \& Sloan, R. (2001). Short sellers, fundamental analysis, and stock returns. Journal of Financial Economics, 61, 77-106. doi:10.1016/S0304-405X(01)00056-3

Dubois, M., \& Louvet, P. (1996). The day-of-the-week effect: International evidence. Journal of Banking and Finance, 20, 1463-1484. doi:10.1016/0378-4266(95)00054-2

French, K. (1980). Stock returns and the weekend effect. Journal of Fi- nancial Economics, 8, 55-69. doi:10.1016/0304-405X(80)90021-5 Gibbons, M., \& Hess, P. (1981). Day of the week effects and asset returns. Journal of Business, 54, 579-596. doi:10.1086/296147

Hindmarch, S., Jentsch, D., \& Drew, D. (1984). A note on Canadian stock returns and the weekend effect. Journal of Business Administration, 14, 163-172.

Jaffe, J., \& Westerfield, R. (1985). The weekend effect in common stock returns: The international evidence. Journal of Finance, 40, 433-454. doi:10.1111/j.1540-6261.1985.tb04966.x

Keim, D. (1989). Trading patterns, bid-ask spread, and estimated security returns. Journal of Financial Economics, 25, 75-89. doi:10.1016/0304-405X(89)90097-4

Keim, D., \& Stambaugh, R. (1984). A further investigation of the weekend effect in stock returns. Journal of Finance, 39, 819-835. doi:10.1111/j.1540-6261.1984.tb03675.x

Lakonishok, J., \& Maberly, E. (1990). The weekend effect: Trading patterns of individual and institutional investors. Journal of Finance, 45, 231-244. doi:10.1111/j.1540-6261.1990.tb05089.x

Sias, R., \& Starks, L. (1995). The day of the week anomaly: The role of institutional investors. Financial Analysts Journal, 51, 58-67. doi:10.2469/faj.v51.n3.1906

Wang, K., Li, Y., \& Erickson, J. (1997). A new look at the Monday effect. Journal of Finance, 52, 2171-2186. doi:10.1111/j.1540-6261.1997.tb02757.x 
W. L. ZHAI ET AL.

Appendix: Basic information about sample indices.

\begin{tabular}{|c|c|c|c|c|c|}
\hline Country & Index & $\begin{array}{l}\text { Starting date } \\
\text { (yyyymmdd) }\end{array}$ & $\begin{array}{l}\text { Legality of } \\
\text { short sales }\end{array}$ & $\begin{array}{c}\text { Feasibility of } \\
\text { short sales }\end{array}$ & $\begin{array}{l}\text { Developed } \\
\text { economy? }\end{array}$ \\
\hline Argentina & BCBA Index: General & 19920101 & Yes & No & No \\
\hline Australia & ASX Index: All Ordinaries & 19860107 & Yes & Yes & Yes \\
\hline Bangladesh & DSE General Index & 20011128 & Yes & Yes & No \\
\hline Belgium & Bel 20 & 20001229 & No & No & No \\
\hline Brazil & BOVESPA & 19920311 & Yes & Yes & Yes \\
\hline Bulgaria & Sofix & 20001023 & Yes & No & No \\
\hline Canada* & TSE 300 & 19800102 & No & No & No \\
\hline Chile & Santiago Stock Exchange Index: IGPA & 19920311 & Yes & Yes & Yes \\
\hline China & SSE Composite Index & 19940103 & Yes & Yes & No \\
\hline Columbia & General IGBC & 20010703 & No & No & No \\
\hline Croatia & CROBEX & 19970102 & No & No & No \\
\hline Czech & PX-GLOB & 20051108 & Yes & Yes & No \\
\hline Denmark & OMXC 20 & 19940103 & Yes & Yes & Yes \\
\hline Egypt & EFG-HERMES Index: EFGI & 19930801 & No & No & No \\
\hline Estonia & OMX Baltic Benchmark GI & 20000103 & No & No & No \\
\hline Finland & OMX Helsinki & 19900102 & Yes & No & Yes \\
\hline France & CAC 40 & 19871231 & Yes & Yes & Yes \\
\hline Germany & DAX & 19880701 & Yes & Yes & Yes \\
\hline Hong Kong & Hang Seng Index & 19900102 & Yes & Yes & Yes \\
\hline Hungary & BUX & 19980107 & No & No & No \\
\hline Iceland & Iceland 15 & 20020206 & Yes & No & Yes \\
\hline India & SENSEX & 19910102 & Yes & No & No \\
\hline Indonesia & JSX composite & 19910102 & No & No & No \\
\hline Ireland & ISEQ Equity Index & 19830103 & Yes & Yes & Yes \\
\hline Israel & TASE Index: TA-25 & 20000103 & No & No & Yes \\
\hline Italy & Mibtel General & 19950102 & Yes & Yes & Yes \\
\hline Japan & TOPIX & 19860106 & Yes & Yes & Yes \\
\hline Jordan & Weighted Share Price Index: General & 19920101 & No & No & No \\
\hline Korea & KRX Index: Korea Composite & 19800104 & Yes & No & Yes \\
\hline Lebanon & BDL Market Value Weighted Index & 19960122 & No & No & No \\
\hline Lithuania & OMX Baltic Benchmark GI & 20000103 & No & No & No \\
\hline Malaysia & KLSE Composite & 19840103 & Yes & Yes & No \\
\hline Mexico & Mexico Stock Exchange IPC Index & 19900419 & Yes & Yes & No \\
\hline Morocco & Casablanca Stock Exchange: MASI & 20050103 & No & No & No \\
\hline Netherlands & Amsterdam All Shares & 20021115 & Yes & Yes & Yes \\
\hline New Zealand & NZX Index: Gross All & 19960820 & Yes & No & Yes \\
\hline Norway* & Oslo Bors Stock Exchange: Benchmark & 20010806 & Yes & Yes & Yes \\
\hline Pakistan & KSE 100 & 19980101 & No & No & No \\
\hline Peru & Lima Stock Exchange: IGBVL & 19990111 & No & No & No \\
\hline Philippines & PSEi & 19940221 & No & No & No \\
\hline Poland & WIG 20 & 20001201 & No & No & No \\
\hline Portugal & PSI 20 & 19921231 & Yes & Yes & No \\
\hline Russia & RTS Stock Exchange Index & 19950901 & No & No & No \\
\hline Saudi Arabia & All Share TASI & 19940126 & Yes & Yes & No \\
\hline Singapore & SGX Index: All Shares & 19860102 & Yes & Yes & Yes \\
\hline Slovakia & SAX & 19950703 & No & No & No \\
\hline Slovenia & SBI 20 & 19921231 & No & No & No \\
\hline South Africa & JSE Index: Major Top 40 & 20060822 & Yes & Yes & No \\
\hline
\end{tabular}


W. L. ZHAI ET AL.

Continued

\begin{tabular}{cccccc}
\hline Spain & IGBM General & 19800102 & Yes & No & Yes \\
Sweden & SSE 30 & 19860930 & Yes & Yes & Yes \\
Switzerland & All Swiss Shares & 19990628 & Yes & Yes & Yes \\
Taiwan & TSEC Index & 19940105 & Yes & Yes & Yes \\
Thailand & SET Index & 19871218 & Yes & Yes & No \\
Turkey & ISE NPI: 1st Sec: 100 & 19981001 & Yes & Yes & No \\
UK & FT 30 & 19860107 & Yes & Yes & Yes \\
Ukraine & PFTS Index & 19971103 & No & No & No \\
U.S. & Dow Jones Index & 19800101 & Yes & Yes & Yes \\
U.S. & S\&P 500 & 19800101 & Yes & Yes & Yes \\
Venezuela & Caracas Stock Exchange Index: IBC & 19940105 & No & No & No \\
\hline
\end{tabular}

"Note: for Canadian market, TSE 300 is used on and before Apr. 30, 2002. On or after May 1, 2002, the TSE 300 is no longer used so we use TSX composite Index instead. For Norway market, Norway index (total) is used on and before September $28^{\text {th }}, 2001$, after that, the Oslo Borse Stock Exchange Benchmark index is used instead because the former is no longer utilized. 